\title{
EFFICIENCY AND PROFITABILITY ON INDONESIAN ISLAMIC BANKING INDUSTRY
}

\author{
Muhammad Nadratuzzaman Hosen, Rafika Rahmawati
}

\begin{abstract}
Efficiency and Profitability On Indonesian Islamic Banking Industry. The aims of this study are to know the level of efficiency and profitability among Islamic full pledge Banks in Indonesia. Using parametric approach namely Stochastic Frontier Approach (SFA) to calculate efficiency and using ROA's ratio to calculate profitability. The result showed that the BMS was the greatest level of efficiency among Islamic Banks in Indonesia which influence the input and output level of efficiency of BMS are personnel expenses, cost-sharing expenses, and total financing which owned. Besides, the result showed that it was the greatest level of profitability which factors influencing of profitability of BMS is BOPO's ratio. The result also showed that the BMI had low efficiency but sufficient profitability. It has sufficient efficiency and high profitability, the BMS have sufficient efficiency and profitability, the BRIS have low efficiency and profitability, and the BSB have high efficiency and low profitability.
\end{abstract}

Keywords: Efficiency, Profitability, Islamic Bank, Stochastic Frontier Analysis

\begin{abstract}
Abstrak. Efisiensi dan Profitabilitas Pada Industri Perbankan Syariah di Indonesia. Tujuan kajian ini adalah untuk mengetahui tingkat efisiensi dan profitabilitas diantara Bank Umum Syariah di Indonesia. Pendekatan yang dipergunakan ialah Stochastic Frontier Analysis (SFA) dalam mengukur tingkat efisiensi dan rasio $R O A$ dalam mengukur tingkat profitabilitas. Hasil kajian menunjukkan bahwa BMS memiliki tingkat efisiensi tertinggi di antara bank umum syariah dimana tingkat efisiensi BMS dipengaruhi oleh biaya sumber daya manusia, biaya bagi hasil dan pembiayaan. Selain itu, BMS memiliki tingkat profitabilitas tertinggi dimana faktor yang memengarubinya ialah rasio BOPO. Hasil kajian juga menunjukkan bahwa BMI memiliki tingkat efisiensi rendah namun tingkat profitabilitas yang baik, BSM tingkat efisiensi yang baik dan tingkat profitabilitas yang tinggi, BMS memiliki tingkat efisiensi dan profitabilitas yang baik, BRIS memiliki tingkat efisiensi dan profitabilitas yang rendah, serta BSB memiliki tingkat efisiensi yang tinggi dan tingkat profitabilitas yang rendah.
\end{abstract}

Kata Kunci: Efisiensi, Profitabilitas, Bank Syariah, Stochastic Frontier Analysis 


\section{Introduction}

Nowadays, Islamic banking in Indonesia continue to need to be able to compete with conventional banks. The opening of the ASEAN Economic Community (AEC), the competition is not only occurs between local banks but also with banks of other countries. Local banks would be difficult to compete with foreign banks because foreign banks are better to offer lower interest rates than local banks. Interest rates on foreign banks are generally offered 3\% in the form of currency, while at the local bank, the interest rate is pegged at least 3.5\% -5\% (Neraca.co.id, 2014).

In order to compete in the industry, Islamic banks are required to operate efficiently, so they can achieve maximum profit and productivity and be able to maintain financial health. The need for performance measurement in Islamic banks is very high, in order to know the level of efficiency and profitability of Islamic banks. According to Berger and Humphrey (1992), there are two general approaches are often used to measure the performance of efficiency in the banking industry namely, traditional and frontier approach. The traditional approach is an approach that compares the financial ratios that exist in the bank. Meanwhile the frontier approach or efficiency frontier approach uses a combination of assets (input-output) in a specific standard.

Measurement of the efficiency of the financial ratios can't detect internal and external factors cause inefficiency. Banking management also cannot be analyzed through financial ratios. Therefore, it is necessary to measure the efficiency to get more good approach. As it is described above, the measurement of efficiency and profitability in Islamic banking is very important. With known levels of efficiency and profitability levels, it will show the overall performance of Islamic banks. There are some factors that cause inefficiencies which can also be known that Islamic banks can do a proper evaluation to improve performance and increase competitiveness.

There are several identification problems from this research: first, what is the level of cost efficiency of Islamic banks in Indonesia period of January 2010 to December 2013 based on parametric approach? Second, what has the greatest influence from component of the input and output on the level of cost efficiency of Islamic banks? Third, what is the level of profitability (Return on Asset/ROA) of Islamic banks in Indonesia period of January 2010 to December 2013 based on parametric approach? Fourth, how Non Performing Financing (NPF), Financing to Deposit Ratio (FDR), Operational Cost Operational Income (BOPO), and Capital Adequacy Ratio (CAR) influence on the level of profitability (Return on Asset/ ROA) in Islamic banks?

The purposes of this research are: first, measure the cost efficiency level of Islamic banks in Indonesia period of January 2010 to December 2013 based on 
parametric approach. Second, analyze the component of input and output which affect the level of cost efficiency of Islamic banks. Third, measure the profitability level of Islamic banks in Indonesia period of January 2010 to December 2013. Fourth, analyze the Non Performing Financing (NPF), Financing to Deposit Ratio (FDR), Operational Cost Operational Income (BOPO), and Capital Adequacy Ratio (CAR) which affect the level of profitability of Islamic banks.

\section{Literature Review}

Haddad, et.al (2003) compared measurements of the Indonesian banking efficiency levels with the method of Stochastic Frontier Approach (SFA) and the method of Distribution Free Approach (DFA). Object of this study are 167 banks operating in the period of January 1995 to June 2003, overall of bank data had been grouped by category. The results of these studies are the efficiency of DFA scores more diverse than the score for SFA if it is used monthly data and annual data that incorporate the entire bank. Nevertheless, the banks most efficiently generated by using both methods remain the same. The results of efficiency calculations based on the SFA and DFA by using a data bank which first grouped by bank category, resulting in the calculation results are not consistent. This inconsistency is probably due to lack of observation of cross section is used, so the diversity of data is reduced. The results of this calculation also concluded that the banks with foreign banks mixed category were the category that most efficiently compared with other categories.

Mokhtar, et.al (2007) studies on technical efficiency and cost efficiency of Islamic bank in Malaysia using methods of Stochastic Frontier Approach in the period 1997 to 2003. Object of study are 20 business units of Islamic, 2 Islamic banks, and 20 conventional commercial banks. The result is known that the average technical efficiency and cost of conventional commercial banks are higher than Islamic banks. However, in terms of trends that the average efficiency of Islamic banks tend to increase from seven periods, while the efficiency of conventional banks did not change much during the same period. Efficiency based on type, Islamic banks are significantly more efficient than Islamic business units. And the average efficiency of banks according to ownership status, it is known that foreign Islamic business units more efficient than domestic banks Islamic business unit.

Al-Timimi (2010) compares factors that influence profitability among Islamic bank with conventional bank for the period of 1996 to 2008. It used regression models $\mathrm{ROA}$ and $\mathrm{ROE}$ as dependent variables. It determaind internal and external factors as independent variables, such as GDP per capita, size of bank, financial development indicator (FIR), liquidity, concentration of bank, cost of bank, and number of branch. The result identification that liquidity and concentration of 
Al-Iqtishad: Jurnal Ilmu Ekonomi Syariah (Journal of Islamic Economics) Vol. 8 (1), January 2016

bank is factors that most significant in conventional bank. Whereas in Islamic bank, factors that most significant are cost of bank and number of branch to influence performance of Islamic bank.

\section{Methods}

Object of the research in this paper is the monthly Financial Report of the Islamic Commercial Bank (BUS) in Indonesia that is Bank of Muamalat Indonesia (BMI), Bank of Shariah Mandiri (BSM), Bank of Mega Shariah (BMS), Bank of BRI Shariah (BRIS), and Bank of Bukopin Shariah (BSB) period January 2010 to December 2013. There are two analysis methods from this research, such as: analysis of efficiency and analysis of profitability.

This paper used the calculation of the efficiency of Islamic banks in terms of costs by using the method of approach cost efficiency, while for the calculations using the method of approach the stochastic frontier approach (SFA) to calculate the deviation of the cost function estimated in advance with its profit frontier.

Cost efficiency is defined as the ratio between the minimum cost which the company can produce a certain output, with the actual costs that incurred by the banking company. The smaller the actual costs are used compared with the minimum cost, and then the level of cost efficiency of banks will be even greater.

In this study, the determination of input and output using Asset Approach as used by Haddad, so that the input and output variables are determined as follows: Input Variables (X) : Price of Labor (P1) and Price of Fund (P2).

Output Variables (Y) : Total Financing (Q1) and Securities which Owned (Q2).

SFA method was developed by Aigner, Lovell, Schmidt (1977). In this method, the cost of a bank's modeled for deviation of its cost efficiency frontier due to random noise and inefficiency.

Standard function of stochastic cost frontier has the general form (log) as follows:

$\ln \mathrm{C}_{\mathrm{i}}=f\left(\ln \mathrm{X}_{\mathrm{ji}}, \ln \mathrm{Y}_{\mathrm{ki}}\right)+e_{\mathrm{i}}$

Where:

$\mathrm{C}_{\mathrm{i}}=$ Total cost of bank $\mathrm{n}$

$\mathrm{X}_{\mathrm{ji}}=$ Input $\mathrm{j}$ of bank $\mathrm{n}$

$\mathrm{Y}_{\mathrm{ji}}=$ Output $\mathrm{k}$ of bank $\mathrm{n}$

$e_{\mathrm{i}}=$ Error 
$e_{i}$ consist of 2 functions:

$e_{i} \quad=u_{i}+v_{i}$

Where :

$u_{i}=$ error factor that can controlled.

$v_{i}=$ error factor that random characteristic that cannot controlled.

Assumption that $\mathrm{v}$ is distribution in normal $\mathrm{N}\left(0, \sigma_{\mathrm{v}}^{2}\right)$ dand $\mathrm{u}$ is distribution in half-normal, $\left|\mathrm{N}\left(0, \sigma_{\mathrm{v}}^{2}\right)\right|$ where $\mathrm{u}_{\mathrm{it}}=\left(\mathrm{u}_{\mathrm{i}} \exp (-\mathrm{h}(\mathrm{t}-\mathrm{T}))^{3}\right.$ and $h$ is parameter that will estimation.

Cost Efficiency is essentially measuring a level of bank's cost compared with a bank that has the best operating cost (best practice bank's cost) that produces the same output with the same technology. Cost efficiency is the derivation of a cost function, eg the cost function with the general form of equation (log) as follows:

$\ln \mathrm{C}=f(\mathrm{w}, \mathrm{y})+\mathrm{e}$

By using the stochastic cost frontier equation form of the cost equation can be written as follows:

$\ln \mathrm{C}=f(\mathrm{w}, \mathrm{y})+\ln u+\ln v$

Where:

$\mathrm{C}=$ total cost atau cost efficiency

$\mathrm{w}=$ total input

$\mathrm{y}=$ total output

$u \operatorname{dan} v=$ error

So, cost efficiency can be writed as follows:

CEFFn $=\frac{\mathrm{C}_{\min }}{\mathrm{C}_{\mathrm{n}}}=\frac{\exp \left[f \mathrm{c}\left(\mathrm{w}^{\mathrm{n}}, \mathrm{y}^{\mathrm{n}}\right)+\ln \left(\mathrm{uc}_{\min }\right)\right]}{\exp \left[f \mathrm{c}\left(\mathrm{w}^{\mathrm{n}}, \mathrm{y}^{\mathrm{n}}\right)+\ln \left(\mathrm{uc}_{\mathrm{n}}\right)\right]}=\frac{\mathrm{uc}_{\min }}{\mathrm{uc}_{\mathrm{n}}} \cdots \cdots$

Profitability levels of BUS were measured by ROA (Return on Assets), the indicator of the ability of banks to earn a return on certain assets owned by the bank. ROA can be obtained by calculating the ratio between profit after tax to total assets (Net Income divided by Total Assets).

After multiple linear regression equation is formed, there should be some test classic assumptions, namely the normality test, autocorrelation test, heteroskedastisitas test, and multicollinearity test.

Then the analysis of hypothesis test are both partially and simultanly. Partial test with $\mathrm{t}$ test and simultan test with $\mathrm{F}$ test. 
In this study, the performance is measured by the level of cost efficiency and the level of profitability (ROA), so here are two models of the regression equation:

Model (I) : Cost Efficiency (CEFF)

$\mathrm{TC}=\alpha_{\mathrm{a}}+\mathrm{b}_{\mathrm{a} 1} \mathrm{P}_{1}+\mathrm{b}_{\mathrm{a} 2} \mathrm{P}_{2}+\mathrm{b}_{\mathrm{a} 3} \mathrm{Q}_{1}+\mathrm{b}_{\mathrm{a} 4} \mathrm{Q}_{2}+\mathrm{e}_{\mathrm{a}}$

Model (II) : Profitability/Return on Assets (ROA)

$\mathrm{ROA}=\alpha_{\mathrm{b}}+\mathrm{b}_{\mathrm{b} 1} \mathrm{NPF}+\mathrm{b}_{\mathrm{b} 2} \mathrm{FDR}+\mathrm{b}_{\mathrm{b} 3} \mathrm{BOPO}+\mathrm{b}_{\mathrm{b} 4} \mathrm{CAR}+\mathrm{e}_{\mathrm{b}}$

Table 1. Research Variables

\begin{tabular}{llll}
\hline Variable & Indicator & Definition & Scale \\
\hline \multirow{2}{*}{ Dependent } & TC & Total Cost & Ratio \\
& ROA & Return on Assets & Ratio \\
& P1 & Price of Labor & Ratio \\
& P2 & Price of Fund & Ratio \\
& Q1 & Total Financing & Ratio \\
& Q2 & Securities which Owned & Ratio \\
& NPF & Non Performing Financing & Ratio \\
& FDR & Financing to Deposit Ratio & Ratio \\
& BOPO & Operational Cost Operational Income & Ratio \\
& CAR & Capital Adequacy Ratio & Ratio \\
\hline
\end{tabular}

\section{Results and Discussion}

\section{Analysis of Cost Efficiency}

By using methods of Stochastic Frontier Approach (SFA) with panel data model, the efficiency of each of the Islamic Commercial Bank can be measured. The panel data is intended to consider the period of observation of a bank and will result in efficiency levels based on the study period that is during the period January 2010 to December 2013.

Form of the model in predicting bank cost efficiency can be written as follows:

$$
\ln \mathrm{TC}=-0,267+0,542 \ln \mathrm{P} 1+0,538 \ln \mathrm{P} 2-0,971 \ln \mathrm{Q} 1+0,109 \ln \mathrm{Q} 2
$$

In the regression equation above, the TC is constant at -0.267 . This means if the input variables and output variables are considered constant the Islamic Commercial Bank will issue a minimum cost for a particular output level that is equal to 0,7657 million of total assets $\left(e^{x}-0,267=0,7657\right)$. The variable Price of Labor $(\ln \mathrm{P} 1)$ coefficient of 0,542 indicates that if the price of labor exponent increased $1 \%$, then the total cost will increase $0,542 \%$. Those results indicate that 
price of labor not give positive contribution to the Islamic Commercial Bank, so as the price of labor is high, the total cost will increase too and will bring inefficiency.

The variable Price of Fund $(\ln \mathrm{P} 2)$ coefficient of 0,538 indicates that if the price of fund exponent increased $1 \%$, then the total cost will increase $0,538 \%$. That result indicates that the Islamic Commercial Bank not optimal manages Deposit Funds. It should deposit funds will increase income for the Islamic Commercial Bank, not be burden because the Islamic Commercial Bank must pay return to the customers that take their money in bank. The variable Total Financing ( $\operatorname{lnQ} 1)$ coefficient of -0,971 indicates that if the total financing exponent increased $1 \%$, then the total cost will decrease $0,971 \%$. Those results indicate that total financing give good return to the Islamic Commercial Bank. But, the Islamic Commercial Bank must immediately increase productivity of financing to increase efficiency in the Islamic Commercial Bank.

Table 2. Level of Cost Efficiency in The Islamic Commercial Bank

\begin{tabular}{lccccc}
\hline \multirow{2}{*}{ Period } & \multicolumn{5}{c}{ Level of Cost Efficiency } \\
& BMI & BSM & BMS & BRIS & BSB \\
\hline March 2010 & 0.9727 & 0.9459 & 0.9277 & 0.7545 & 0.9051 \\
June 2010 & 0.9697 & 0.9032 & 0.9329 & 0.8827 & 0.8737 \\
September 2010 & 0.9567 & 0.8825 & 0.8951 & 0.8162 & 0.8716 \\
December 2010 & 0.9467 & 0.8417 & 0.8754 & 0.8096 & 0.8913 \\
March 2011 & 0.8491 & 0.9708 & 0.9701 & 0.8399 & 0.9531 \\
June 2011 & 0.8356 & 0.8247 & 0.9378 & 0.7630 & 0.9769 \\
September 2011 & 0.8452 & 0.8081 & 0.9452 & 0.6433 & 0.9548 \\
December 2011 & 0.7940 & 0.8093 & 0.9177 & 0.6960 & 0.9560 \\
March 2012 & 0.7774 & 0.8445 & 0.9838 & 0.9549 & 0.9866 \\
June 2012 & 0.7841 & 0.8482 & 0.9441 & 0.7948 & 0.9441 \\
September 2012 & 0.7831 & 0.8645 & 0.9022 & 0.7944 & 0.9683 \\
December 2012 & 0.7559 & 0.8705 & 0.8828 & 0.8644 & 0.9557 \\
March 2013 & 0.7845 & 0.8980 & 0.9715 & 0.7100 & 0.6231 \\
June 2013 & 0.7674 & 0.9322 & 0.9340 & 0.7339 & 0.5492 \\
September 2013 & 0.7444 & 0.9281 & 0.9122 & 0.7795 & 0.5935 \\
December 2013 & 0.7585 & 0.9009 & 0.8484 & 0.6984 & 0.5837 \\
\multicolumn{1}{c}{ Average } & $\mathbf{0 , 8 3 2 8}$ & $\mathbf{0 , 8 7 9 6}$ & $\mathbf{0 , 9 2 3 8}$ & $\mathbf{0 , 7 8 3 5}$ & $\mathbf{0 , 8 4 9 2}$ \\
\hline
\end{tabular}


The variable Securities which Owned (lnQ2) coefficient of 0,109 indicates that if the Securities which owned exponent increased $1 \%$, then the total cost will increase $0,109 \%$. That result indicate that Securities which Owned by the Islamic Commercial Bank give return lower than cost that must the Islamic Commercial Bank pay. The result of cost efficiency on Islamic Commercial Bank in Indonesia period of January 2010 to December 2013. The average level of cost efficiency Islamic Commercial Bank period January 2010 to December 2013, the highest achieved by BMS that is equal to 0.9238 or $92.38 \%$. Islamic Commercial Bank with a lowest level of cost is efficiency achieved by BRIS that is equal to 0.7835 or $78.35 \%$.

Table 3. Category of Cost Efficiency

\begin{tabular}{cc}
\hline Level of Cost Efficiency & Category \\
\hline $65 \%-85 \%$ & Low Efficiency \\
$86 \%-96 \%$ & Medium Efficiency \\
$97 \%-100 \%$ & High Efficiency \\
\hline
\end{tabular}

From these results, it shows that the five Islamic Commercial Banks has not reached the optimum level of efficiency. Therefore, the increase in cost efficiency needs to be continued. The cost efficiency level of five Islamic Commercial Bank also looks have variation ranging from 0.7835 (BRIS efficiency level) up to 0.9238 (BMS efficiency level). It is proved that every Islamic Commercial Bank has managerial implementation strategies vary in terms of reduced cost-sharing, suppression personnel costs, investment arrangements, and so on.

Table 4. Grouping of Level of Cost Efficiency

\begin{tabular}{ccc}
\hline The Islamic Commercial Bank & Level of Cost Efficiency & Category \\
\hline Bank of Muamalat Indonesia & $83,28 \%$ & Low \\
Bank of Shariah Mandiri & $87,96 \%$ & Medium \\
Bank of Mega Shariah & $92,38 \%$ & Medium \\
Bank of BRI Shariah & $78,35 \%$ & Low \\
Bank of Shariah Bukopin & $84,92 \%$ & Low \\
\hline
\end{tabular}


So, all the Islamic Commercial Bank can be rated, as in Table 4. Table 4 showed BSM and BMS into category medium of cost efficiency. Whereas BMI, BRIS, and BSB into category of low cost efficiency.

Table 5. Level of Profitability in The Islamic Commercial Bank

\begin{tabular}{|c|c|c|c|c|c|}
\hline \multirow{2}{*}{ Period } & \multicolumn{5}{|c|}{ Level of Profitability } \\
\hline & BMI & BSM & BMS & BRIS & BSB \\
\hline March 2010 & $1,48 \%$ & $2,04 \%$ & $3,18 \%$ & $1,12 \%$ & $0,65 \%$ \\
\hline June 2010 & $1,07 \%$ & $2,22 \%$ & $2,98 \%$ & $0,97 \%$ & $0,59 \%$ \\
\hline September 2010 & $0,81 \%$ & $2,30 \%$ & $2,47 \%$ & $0,24 \%$ & $0,43 \%$ \\
\hline December 2010 & $1,36 \%$ & $2,21 \%$ & $1,90 \%$ & $0,35 \%$ & $0,74 \%$ \\
\hline March 2011 & $1,38 \%$ & $2,22 \%$ & $1,77 \%$ & $0,23 \%$ & $0,62 \%$ \\
\hline June 2011 & $1,74 \%$ & $2,12 \%$ & $1,87 \%$ & $0,20 \%$ & $0,65 \%$ \\
\hline September 2011 & $1,55 \%$ & $2,03 \%$ & $1,65 \%$ & $0,40 \%$ & $0,51 \%$ \\
\hline December 2011 & $1,52 \%$ & $1,95 \%$ & $1,58 \%$ & $0,20 \%$ & $0,52 \%$ \\
\hline March 2012 & $1,51 \%$ & $2,17 \%$ & $3,52 \%$ & $0,17 \%$ & $0,54 \%$ \\
\hline June 2012 & $1,61 \%$ & $2,25 \%$ & $4,13 \%$ & $1,21 \%$ & $0,52 \%$ \\
\hline September 2012 & $1,62 \%$ & $2,22 \%$ & $4,11 \%$ & $1,34 \%$ & $0,61 \%$ \\
\hline December 2012 & $1,54 \%$ & $2,25 \%$ & $3,81 \%$ & $1,19 \%$ & $0,55 \%$ \\
\hline March 2013 & $1,72 \%$ & $2,56 \%$ & $3,57 \%$ & $1,71 \%$ & $1,08 \%$ \\
\hline June 2013 & $1,69 \%$ & $1,79 \%$ & $2,94 \%$ & $1,41 \%$ & $1.04 \%$ \\
\hline September 2013 & $1,68 \%$ & $1,51 \%$ & $2,57 \%$ & $1,36 \%$ & $0,79 \%$ \\
\hline December 2013 & $1,37 \%$ & $1,53 \%$ & $2,33 \%$ & $1,15 \%$ & $0,69 \%$ \\
\hline Average & $1,48 \%$ & $2,09 \%$ & $2,77 \%$ & $0,83 \%$ & $0,59 \%$ \\
\hline
\end{tabular}




\section{Analysis of Profitability}

The indicators that used to measure the performance of the bank's profitability is ROA (Return on Assets) is the ratio that indicates the ability of the entire existing assets and are used to generate a profit. Here are the results of the average level of profitability (ROA) in the 2010-2013 from five Islamic commercial banks; it can be seen at Table 5. It is known that Islamic Commercial Bank with the highest of profitability level in the period 2010-2013, it is Bank of Mega Shariah (BMS) that is equal to $2.77 \%$. While the lowest profitability, it is Bank of Shariah Bukopin (BSB) that is equal to $0.59 \%$. From these results, it is known that the Islamic commercial Banks (BUS) with large assets such as Bank of Shariah Mandiri (BSM) is not a factor to be able to achieve great profitability.

The result of profitability level above if we take to a category, can be seen at Table 6.

Table 6. Category of Level of Profitability

\begin{tabular}{cc}
\hline Level of Profitability & Category \\
\hline $0 \%-0,99 \%$ & Low Profitability \\
$1,00 \%-1,99 \%$ & Medium Profitability \\
$2,00 \%-\infty$ & High Profitability \\
\hline
\end{tabular}

According Table 7, that BMI into category medium of profitability. Whereas BSM and BMS into category high of profitability. BRIS and BSB into category low of profitability.

Table 7. Grouping of Level of Profitability

\begin{tabular}{lcc}
\hline The Islamic Commercial Bank & Level of Profitability & Category \\
\hline Bank Muamalat Indonesia & $1,48 \%$ & Medium \\
Bank Syariah Mandiri & $2,09 \%$ & High \\
Bank Mega Syariah & $2,77 \%$ & High \\
BRI Syariah & $0,83 \%$ & Low \\
Bank Syariah Bukopin & $0,59 \%$ & Low \\
\hline
\end{tabular}




\section{Analysis of Multiple Linear Regression \\ Cost Efficiency (CEFF)}

Based on the test results of the classical assumptions (OLS test), it can be concluded that the regression model is normally distributed, contains no autocorrelation, heteroscedasticity, but still there is a problem of multicollinearity.

Then regression result in Model 1, can be summarize as follow. First, we see from the adjusted R Square test $\left(\operatorname{Adj} R^{2}\right)$. To find out how much the independent variables simultaneously can explain the dependent variable can be seen from the Adjusted R Square atau Adj R².

Table 8. Result of Adjusted R Square (Adj R²)

\begin{tabular}{cccccc}
\hline \multirow{2}{*}{ Adj $\mathbf{R}^{2}$} & BMI & BSM & BMS & BRIS & BSB \\
\cline { 2 - 6 } & 0,987 & 0,988 & 0,998 & 0,926 & 0,964 \\
\hline
\end{tabular}

Second, to determine the significance of the influence of all independent variables simultaneously on the dependent variable used $\mathrm{F}$ test, ie by comparing $\mathrm{F}_{\text {hitung }}$ generated by multiple linear regression with $\mathrm{F}_{\text {tabel }}$ in the significant level of $95 \%(\alpha=$ $5 \%)$. Here are the results of $\mathrm{F}$ test from each of the Islamic Commercial Bank. It is known that $\mathrm{F}$ table with level $=5 \%, \mathrm{df}_{1}=4$ and $\mathrm{df}_{2}=43$, obtained $\mathrm{F}_{\text {tabel }}$ is 2,61 . While the F-test each BUS obtained $\mathrm{F}_{\text {hitung }}$ BMI is $888,409, \mathrm{BSM}$ is 937,703 , BMS is 6,446, BRIS is 148,221 , and BSB is 313,708 . Thus, it can be concluded that the entire $\mathrm{F}_{\text {hitung }}$ BUS greater than $\mathrm{F}_{\text {tabel }}$, so that $\mathrm{H}_{0}$ is rejected and $\mathrm{H}_{\mathrm{a}}$ accepted. That is, there are input and output variables have a significant influence together on the efficiency of the BUS.

Third, t-test used to test the strength of the relationship of each independent variable on the dependent variable individually. By comparing the values obtained $t_{\text {hitung }}$ with $t_{\text {table }}$ of each variable using 95\% significant level $(\alpha=5 \%)$. Here are the results of the $\mathrm{t}$ test of each the Islamic Commercial Bank.

Table 9. Result of t-Test of Level Efficiency the Islamic Commercial Bank

\begin{tabular}{cccccc}
\hline Variable & BMI & BSM & BMS & BRIS & BSB \\
\hline Cost of Labor & Significant $(+)$ & No Significant & Significant $(+)$ & $\begin{array}{c}\text { No } \\
\text { Significant }\end{array}$ & Significant $(+)$ \\
Cost of Fund & Significant $(+)$ & Significant $(+)$ & Significant $(+)$ & Significant $(+)$ & Significant (-) \\
Total & Significant $(+)$ & No Significant & Significant $(-)$ & Significant $(-)$ & Significant (+) \\
$\begin{array}{c}\text { Financing } \\
\text { Securities }\end{array}$ & Significant $(-)$ & Significant $(-)$ & $\begin{array}{c}\text { No } \\
\text { Significant }\end{array}$ & Significant $(-)$ & $\begin{array}{c}\text { No } \\
\text { Significant }\end{array}$ \\
\hline
\end{tabular}




\section{Profitabilitas/Return on Assets (ROA)}

Based on the test results of the classical assumptions (OLS test), it can be concluded that the regression model is normally distributed, contains no autocorrelation, heteroscedasticity, and multicollinearity.

Then regression result in Model 2, can be summarize as follow: First, we see from the adjusted $\mathrm{R}$ Square test $\left(\operatorname{Adj} \mathrm{R}^{2}\right)$. To find out how much the independent variables simultaneously can explain the dependent variable can be seen from the Adjusted R Square atau Adj R².

Table 10. Result of Adjusted R Square (Adj R²)

\begin{tabular}{llllll}
\hline \multirow{2}{*}{ Adj R $^{2}$} & BMI & BSM & BMS & BRIS & BSB \\
\cline { 2 - 6 } & 0,778 & 0,889 & 0,895 & 0,772 & 0,822 \\
\hline
\end{tabular}

Second, to determine the significance of the influence of all independent variables simultaneously on the dependent variable used F test, such as by comparing $\mathrm{F}_{\text {hitung }}$ generated by multiple linear regression with $\mathrm{F}_{\text {tabel }}$ in the significant level of $95 \%(\alpha=5 \%)$. Here are the results of $\mathrm{F}$ test from each of the Islamic Commercial Bank. It is known that $\mathrm{F}$ table with level $=5 \%, \mathrm{df}_{1}=4$ and $\mathrm{df}_{2}=43$, obtained $\mathrm{F}_{\text {tabel }}$ is 2,61. While the F-test each BUS obtained $\mathrm{F}_{\text {hitung }} \mathrm{BMI}$ is 42,178; BSM is 95,459; BMS is 101,519 ; BRIS is 40,880 ; and BSB is 55,246 . Thus, it can be concluded that the entire $\mathrm{F}_{\text {hitung }}$ BUS greater than $\mathrm{F}_{\text {tabel}}$, so that $\mathrm{H}_{0}$ is rejected and $\mathrm{H}_{\mathrm{a}}$ accepted. That is, there are independent variables (NPF, FDR, BOPO, and CAR) have a significant influence together on the profitability of the BUS. Third, t-test used to test the strength of the relationship of each independent variable on the dependent variable individually. By comparing the values obtained $t_{\text {hitung }}$ with $t_{\text {table }}$ of each variable using 95\% significant level $(\alpha=5 \%)$. Here are the results of the t test of each the Islamic Commercial Bank:

Table 11. Result of t-Test of Profitability the Islamic Commercial Bank

\begin{tabular}{cccccc}
\hline Variable & BMI & BSM & BMS & BRIS & BSB \\
\hline NPF & No Significant & No Significant & No Significant & No Significant & No Significant \\
& & & & & \\
FDR & Significant (-) & No Significant & No Significant & Significant (-) & Significant (+) \\
BOPO & Significant (-) & Significant $(-)$ & Significant $(-)$ & No Significant & Significant (-) \\
CAR & Significant (-) & No Significant & No Significant & Significant (+) & No Significant \\
\hline
\end{tabular}


From two method of calculation of the performance of the five-BUS has been analyzed previously, namely the approach of cost efficiency and profitability, it can be seen.

Table 12. The Islamic Commercial Bank Performance in Period 2010-2013

\begin{tabular}{ccc}
\hline BUS & Category of Cost Efficiency & Category of Profitability \\
\hline Bank Muamalat Indonesia & Low & Medium \\
Bank Syariah Mandiri & Medium & High \\
Bank Mega Syariah & Medium & High \\
BRI Syariah & Low & Low \\
Bank Syariah Bukopin & Low & Low \\
\hline
\end{tabular}

From the Table 12, it can be seen that there are inconsistencies between the results of the method efficiency and profitability. The BMI is known that has a low level of cost efficiency and has a medium profitability. That is, BMI has not emphasized the efficient of fund's management; BMI has not cut costs that are not important, so that the profitability of the acquired BMI becomes optimal.

The BSM known that has an efficiency level is medium and has a high profitability. That is, BSM has a sufficient good fund management, because it can minimize costs and can manage their funds in profitable sectors. As BUS with the largest total assets, BSM is able to compete well. The BMS known that have medium levels of cost efficiency and has a high profitability. That is, BMS still need to do a cost-efficiency, because there are costs that do not matter much incurred by BMS. However, BMS have long operated able to obtain a fairly good profitability, although not optimal. The BRIS known that have a low level of cost efficiency and low profitability. That is, BRIS must continue to improve cost efficiency by minimizing costs that are not important and do not add to profitability. With more efficient expected level of profitability BRIS will also increase. The BSB is known that has a low level of cost efficiency and low profitability. That is, the management of funds in BSB has not been good. BSB has not been able to minimize the costs that are not important. Therefore, BSB should be able to place their funds in investments that provide good profit, so the profitability of the BSB can be increased and the profitability can reduce the cost burden on the BSB. 


\section{Conclusion}

During the period January 2010 until December 2013 the average level of the largest cost efficiency of Islamic Commercial Bank in Indonesia is on BMI amounting to $83,28 \%$; BSM is $87,96 \%$; BMS is $92,38 \%$; BRIS $78,35 \%$; and BSB $84,92 \%$. The hypothesis of this study which states that there is influence between component inputs (cost of labor and cost of fund) and output (total financing and securities which owned) to the level of cost efficiency simultaneously, can be accepted. Where the BMI amounting to $98,7 \%$ and its influence on the BSM influence $98,8 \%$, and the BMS effect of $99,8 \%$. On BRIS effect of $92,6 \%$, and the BSB effect 96,4\%. During the period January 2010 until December 2013 the average level of the largest profitability of Islamic Commercial Bank in Indonesia is on $\mathrm{BMI}$ amounting to $1,48 \%$; $\mathrm{BSM}$ is $2,09 \%$; $\mathrm{BMS}$ is $2,77 \%$; BRIS $0,83 \%$; and BSB $0,59 \%$. The hypothesis of this study which states that there is influence between NPF, FDR, BOPO, and CAR to the level of profitability simultaneously, can be accepted. Where the BMI amounting to $77,8 \%$ and its influence on the BSM influence $88,9 \%$, and the BMS effect of $89,5 \%$. On BRIS effect of $77,2 \%$, and the BSB effect $82,2 \%$.

There are several recommendations that suggested by this research. First, to management each the Islamic Commercial Bank, to continue to raise the level of cost efficiency, because from the cost is still no funds are not used efficiently. It can be seen from the level of cost efficiency that has not reached 100\%. Second, in level of profitability, management each the Islamic Commercial Bank have to raise the level of profitability because level of ROA still low. The need for the placement of funds in order to fund the existing productive can generate profits greater. Third, for further research, the determination of the independent variables to be more numerous and varied to model better formulated. In addition, it should be associated with the level of liquidity BUS.

\section{References}

Al-Tamimi, H.A.H. (2010). Factors Influencing Performance of The UEA Islamic and Conventional National Banks. Global Journal of Bussiness Research, Volume 4 No.2, pp. 1-10.

Akhtar, M.F, et al. (2011). Factors Influencing The Probability of Islamic Banks of Pakistan. International Research Journal of Finance and Economics. Issues 66, pp. 126-132. 
Berger, A.N. \& Humphrey, D.B. (1997). Efficiency of Financial Institutions: International Survey and Directions for Future Research. European Journal of Operational Research, Volume 98, pp 175-212.

Gozali, I. (2007). Pengaruh CAR (Capital Adequacy Ratio), FDR (Financing to Deposit Ratio), BOPO (Biaya Operasional Terhadap Pendapatan Operasional) dan NPL (Non Performing Loan) Terhadap Profitabilitas Bank Syariah Mandiri (January:2004 - Oktober:2006). (Unpublished Thesis). Yogyakarta: Universitas Islam Indonesia.

Haddad, M.D. et.al. (2003) "Analisis Efisiensi Industri Perbankan Indonesia: Penggunaan Metode Nonparametrik Data Envelopment Analysis (DEA)." Jurnal Bank Indonesia, Desember 2003.

Hartono, E. (2009). Analisis Efisiensi Biaya Industri Perbankan Indonesia Dengan Menggunakan Metode Parametrik Stochastic Frontier Analysis (Studi Pada Perbankan yang Terdaftar di Bursa Efek Indonesia Periode 2004-2007). (Unpublished Thesis). Semarang: Universitas Diponegoro.

Idris et. al. (2011). Determinant of Islamic Banking Institutions' Profitability in Malaysia. World Applied Sciences Journal 12. pp. $1-7$.

Idroes, F.N \& Sugiarto. (2006). Manajemen Risiko Perbankan Dalam Konteks Kesepakatan Basel dan Peraturan Bank Indonesia. Yogyakarta: Graha Ilmu.

Kusmargiani, I.S. (2006). Analisis Efisiensi Operasional dan Efisiensi Profitabilitas Pada Bank yang Merger dan Akuisisi di Indonesia (Studi Pada Bank Setelah Rekapitalisasi dan Restrukturisasi Tahun 1999-2002). (Unpublished Thesis). Semarang: Universitas Diponegoro.

Mokhtar, H.S.A, et.al. (2006). Efficiency of Islamic Banking in Malaysia, A Stochastic Frontier Approach. Journal of Economic Cooperation. Vol.2 (27), pp. 37-70.

Muhari, S. \& Hosen, M.N. (2013). Efficiency of the Islamic Rural Bank in Indonesia Lead to Modified CAMEL. Journal of Academic Research in economics and Management Sciences. Vol.2 (5), pp. 34-53.

Rahmawati, R \& Hosen, M.N. (2012). Efficiency of Fund Management of Islamic Banking in Indonesia (Based on Parametric Approach). International Journal of Academic Research in Economics and Management Sciencies. Vol. 1. (2), pp. 144-157.

Yaumidin, U.K. (2007). Efficiency in Islamic Banking: A Non-Parametric Approach. Buletin Ekonomi Moneter dan Perbankan, Volume 9 number 4, pp. 23-55. 
Al-Iqtishad: Jurnal Ilmu Ekonomi Syariah (Journal of Islamic Economics) Vol. 8 (1), January 2016

Yilmaz, A.A. (2013). Profitability of Banking System: Evidence from Emerging Markets. WEI International Academic Conference Proceedings, January 14-16, 2013, Antalya Turkey: pp. 105-111. 